\title{
Growth Characteristics Of Guinea Grass on the Semiarid South Coast Of Puerto Rico, and the Effect Of Nitrogen Fertilization on Forage Yields and Protein Content
}

\section{José Vicente-Chandler and Jacinto Figarella ${ }^{1}$ \\ INTRODUCTION}

There is little effective moisture available during the 5-month dry season (December to April) which affects the south coast of Puerto Rico, and the nonirrigable lands of this area are best suited for use as permanent pastures. Much of this land is in Guinea grass (Panicum maximum), and the evidence available at present indicates that it is the best forage for this region.

The steepness of most of this land limits the use of silage; the unpredictable rainfall and other factors make the use of hay impractical. Cattle must therefore subsist during the critical dry season largely on the forage carried over in the field from the wet period. Since pasturage is abundant during the rainy season, the quantity and quality of this "carry-over" forage generally limits the stocking level and therefore the over-all productivity of livestock farms in this region.

The soils of the south coast are generally fertile and nitrogen seems to be the main limiting nutrient for forage crops. There is very little information available, however, on the effect of nitrogen fertilization upon Guinea grass in this region.

\section{OBJECTIVE}

This study was carried out to determine the effect of nitrogen fertilizer applied to a closely grazed Guinea grass pasture toward the end of the wet season on the yield and protein content of the forage produced for "carryover" into the dry season. The changes in the protein content of the forage as it dried out in the field and the effect of the treatments on the forage produced during the subsequent rainy season were also studied.

\section{MATERIALS AND METHODS}

The rainfall data available for the south coast of Puerto Rico were examined to determine the rainfall pattern of this area and provide a basis

${ }^{1}$ Project Supervisor and Soil Scientist, respectively, of a research project cooperative between the Agricultural Research Service of the United States Department of Agriculture and the Agricultural Experiment Station of the University of Puerto Rico, Río Piedras, P. R. 
for predicting when the dry season was likely to start. A record of rainfall was kept at the experimental site near Coamo, P. R., where conditions typical of the semiarid south coast prevail.

The area selected for the experiment had an excellent stand of Guinea grass and since the soil was well provided with phosphorus and potassium, no fertilizer was applied other than nitrogen as called for by the treatments. The soil is a deep, sloping Coamo clay. The surface soil has a $\mathrm{pH}$ of 6.2 , a total exchange capacity of 35.4 m.e. per $100 \mathrm{gm}$. of soil, a total exchangeable base content of $29.4 \mathrm{~m}$.e. per $100 \mathrm{gm}$. of soil, and an organic-matter content of 3.4 percent, with a $\mathrm{C}: \mathrm{N}$ ratio of about 10 .

A preliminary study was carried out during the first rainy season, when moisture was abundant, to determine the effect of stage of growth on protein content and on the dry-matter and protein yields of Guinea grass when heavily fertilized with nitrogen. The grass in a 40-x-40-foot area was cut and 400 pounds per acre of nitrogen were applied in the form of ammonium sulfate. Four plots $4 \times 4$ feet in area were harvested every 20 days. The forage was weighed and dried and its protein content determined.

Another preliminary study was carried out starting on November 1, 1953, to determine the changes in the protein content of various portions of the Guinea grass plant as it grew and then dried out in the field. The forage was cut back and 400 pounds of nitrogen in the form of ammonium sulfate were applied per acre. Six plants were dug up at monthly intervals and were divided into roots, stems, leaf sheaths, and leaves. These were analyzed to determine their protein content.

On November 1, 1953, the forage in the experimental area was cut back and the treatments $-0,100,200$, and 400 pounds of nitrogen per acre in the form of ammonium sulfate-applied. All treatments were replicated four times. Plots were $10 \times 20$ feet in size with a 2 -foot buffer zone around each.

Forage samples were taken from all plots at monthly intervals and analyzed to determine their nitrogen content. In addition, composited samples for all treatments were analyzed for soluble nitrogen. All plots were harvested toward the end of the dry season, May 1, and twice during the following rainy season, and yields and protein determinations were made. The experiment was repeated in the same manner starting on November 1 , 1954 .

\section{RESULTS}

THE RAINFALL PATTERN OF THE SOUTH COAST

The average monthly rainfall at seven locations throughout the south coast is shown in table 1. There does not appear to be much difference in the over-all pattern of rainfall in this area, with the exception of Lajas 
where precipitation seems to be better distributed throughout the year than at other locations. Average annual rainfall for this region is about 36.5 inches with almost all the effective precipitation (about 29 inches) falling during the 7-month period of May to November. The inch or so of monthly rainfall which can be expected during the remainder of the year produces very little plant growth since it occurs largely in the form of dew or very light showers at a time when climatic conditions favor very rapid evaporation.

TABLE 1.-10-year average rainfall by months at 7 locations throughout the semiarid south coast of Puerto Rico

\begin{tabular}{|c|c|c|c|c|c|c|c|c|}
\hline Month & Aguirre & Potala & Coamo & $\begin{array}{l}\text { Santa } \\
\text { Isabel }\end{array}$ & Yauco & Ensenada & Lajas & Average \\
\hline January & 1.40 & 0.78 & 1.18 & 1.12 & 0.92 & 0.79 & 1.40 & 1.08 \\
\hline February & 1.48 & 1.18 & 1.11 & 1.06 & 1.54 & 1.42 & 1.64 & 1.35 \\
\hline March & 1.19 & .92 & .63 & .87 & 1.14 & 1.28 & 3.18 & 1.32 \\
\hline April & 1.96 & 2.00 & 1.78 & 1.55 & 1.84 & 1.82 & 2.13 & 1.87 \\
\hline May & 4.40 & 4.16 & 4.54 & 3.82 & 5.54 & 3.58 & 2.02 & 4.01 \\
\hline June & 4.48 & 2.72 & 2.89 & 2.96 & 2.65 & 2.25 & 2.11 & 2.87 \\
\hline July & 4.12 & 2.65 & 2.17 & 2.54 & 2.38 & 2.00 & 5.16 & 3.00 \\
\hline August & 4.90 & 4.09 & 5.12 & 3.85 & 4.86 & 3.06 & 4.63 & 4.36 \\
\hline September & 6.06 & 5.44 & 6.18 & 4.89 & 6.02 & 4.62 & 5.95 & 5.59 \\
\hline October & .5 .93 & 5.18 & 5.70 & 5.61 & 4.92 & 4.26 & 3.94 & 5.08 \\
\hline November & 4.51 & 3.77 & 4.07 & 3.94 & 3.83 & 3.84 & 4.30 & 4.04 \\
\hline December & 1.84 & 1.10 & 1.68 & 1.53 & 1.34 & 1.52 & 4.54 & 1.92 \\
\hline Total & 42.27 & 33.99 & 37.05 & 33.74 & 36.98 & 30.44 & 41.00 & 36.49 \\
\hline
\end{tabular}

\section{THE GROWTH PATTERN OF GUINEA GRASS}

The effect of stage of growth on the dry-matter and protein yields and protein content of heavily fertilized Guinea grass growing with abundant moisture is shown in figure 1.

These data show that Guinea grass grows rapidly for a period of about 80 days after which its growth rate declines. The protein content of the forage decreases rapidly with age. Yields of crude protein increase with age up to about 80 days after which they remain about constant, the rise in yield after this date, apparently compensating for the continued drop in protein content.

From the above it appears that, in order to obtain a large quantity of carry-over forage of a desirable protein content for use during the dry season, the growth of Guinea grass should be stopped by drouth when it is between 60 and 80 days of age. Thus, for this purpose, pastures should be cut or grazed closely and fertilizer applied in October or early November. 
Before growth is stopped by drouth the grass can make use of 6 to 11 inches of rainfall which can be expected during the remainder of the calendar year and which is sufficient to allow the grass to grow for a desirable period.

\section{EFFECT OF MATURITY ON THE PROTEIN CONTENT \\ OF SECTIONS OF THE GUINEA GRASS PLANT}

As will be shown later, traces only of soluble nitrogen were found in the forage. The assumption is therefore made that the nitrogen found by analysis is present in amino form and nitrogen multiplied by 6.25 is reported as protein.



FIG. 1.-Variation with age in the dry-matter and protein yields and protein . content of heavily fertilized Guinea grass growing with abundant moisture.

The data in table 2 show the changes occurring with age in the protein content of sections of heavily fertilized Guinea grass when carried over into the dry season. The protein content of the total forage decreased rapidly with age. That of the roots, stems, and leaf sheaths, however, did not vary much over the 6-month period of the study. On the other hand, the protein content of the leaves, although always higher than that of the other sections, dropped steadily with age from 24.4 percent, when the grass was 1 month old, to 14.6 percent at an age of 6 months. It seems that the drop with age in the protein content of the total forage was partly caused by the decrease in the protein content of the leaves, but more so by an increase in the proportion of stems and leaf sheaths.

\section{THE EFEECT OF NITROGEN FERTIIIZATION}

The results of the experiment carried out to determine the effect of nitrogen fertilization on the yield and protein content of Guinea grass are 
summarized in table 3. During the first year weather conditions were about normal and the plots received sufficient rainfall after being cut back and fertilized so that the grass produced an abundance of forage for carrying over into the dry season. During the second year the drouth started shortly after the trials were initiated and seriously limited the quantity of carryover forage. The data shown are therefore representative of what can be expected under both these conditions. The first year's results are discussed in more detail since they represent normal conditions.

\section{Carry-over forage}

The quantity of dry matter produced during the first year for carry-over into the dry season was increased significantly, from 3,555 to 5,520 pounds

TABLE 2.-Changes with maturity in the percentage protein content of different sections of Guinea grass cut and fertilized with 400 pounds of nitrogen per acre on November 1, 1959

\begin{tabular}{c|c|r|r|r|r}
\hline Date & Roots & Stem & Leaf sheath & Leaves & $\begin{array}{c}\text { Total forage (above- } \\
\text { ground portions) }\end{array}$ \\
\cline { 1 - 2 } Dec. 1 & 7.2 & 9.2 & 10.1 & 24.4 & 22.7 \\
Jan. 1 & 6.9 & 10.6 & 9.1 & 18.5 & 13.4 \\
Feb. 1 & 7.8 & 9.6 & 8.7 & 15.8 & 10.5 \\
Mar. 1 & 7.3 & 11.0 & 8.8 & 15.6 & 10.7 \\
Apr. 1 & 6.8 & 7.4 & 8.8 & 13.8 & 9.4 \\
May 1 & 7.1 & 8.4 & 8.9 & 14.6 & 9.3 \\
\hline
\end{tabular}

${ }^{1}$ All values are averages of 6 samples.

per acre, by an application of 100 pounds of nitrogen per acre. Heavier applications of nitrogen had no apparent effect on yields. During the second year the drouth which started soon after the treatments were applied greatly curtailed plant growth, and nitrogen fertilization had no significant effect on yields.

Nitrogen fertilization over both years had a marked effect on the protein content of the forage carried over into the dry season and allowed to dry in the field. The protein content of the forage tended to increase with each increment of nitrogen fertilization up to the highest level tested (400 pounds per acre). This effect was apparent at all ages, although the protein content in all cases dropped rapidly as the grass matured and dried out. Application of 100 pounds of nitrogen per acre increased the protein content of the herbage significantly at all ages during both years.

At 1 month the protein content of heavily fertilized Guinea grass was comparable to that of good legume hay. At the end of the dry season of the first year, when the grass was about 6 months old, the untreated forage had 


\begin{tabular}{|c|c|c|c|c|c|c|}
\hline \multirow{3}{*}{ 丞 } & 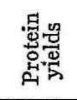 & 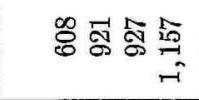 & & 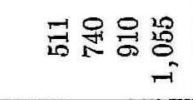 & & 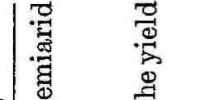 \\
\hline & 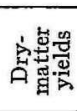 & 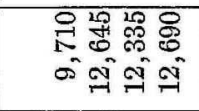 & $\begin{array}{l}\mathscr{8} \\
\dot{8}\end{array}$ &  & 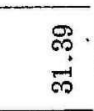 & $\mid \begin{array}{l}0 \\
0 \\
\frac{1}{+} \\
w \\
0\end{array}$ \\
\hline & 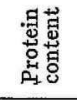 & 年 & & 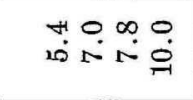 & & . \\
\hline 范 & 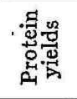 & 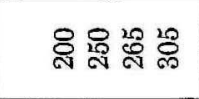 & &  & & 总 \\
\hline 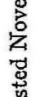 & 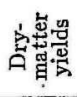 & 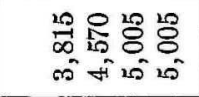 & 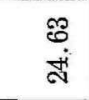 &  & $\begin{array}{l}10 \\
20 \\
0\end{array}$ & 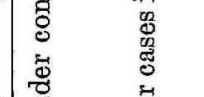 \\
\hline 总 & 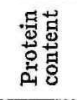 & 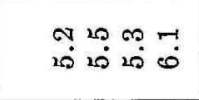 & & مُ & & ב \\
\hline ت. & 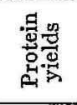 & 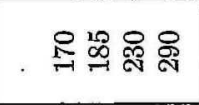 & & 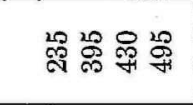 & & + \\
\hline 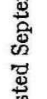 & 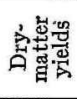 & 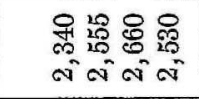 & $\begin{array}{l}\text { : } \\
\stackrel{9}{0} \\
\stackrel{1}{-1}\end{array}$ & 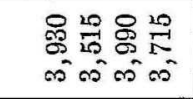 & 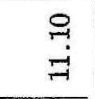 & . \\
\hline 莺 & 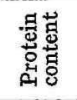 & مُ & & 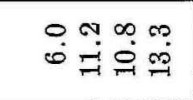 & & 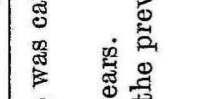 \\
\hline $\overrightarrow{\mathrm{c}}$ & 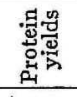 & 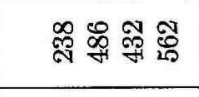 & & 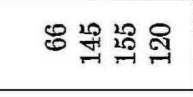 & & 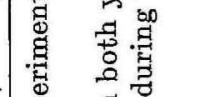 \\
\hline 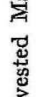 & 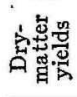 & 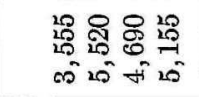 & 芒 & 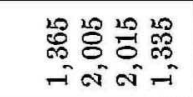 & 感 & 产 \\
\hline 预 & 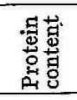 & $\begin{array}{l}0 \infty \\
\dot{\omega} \infty \\
\infty\end{array}$ & &  & &  \\
\hline $1^{\circ}$ & 至 & .. & $\begin{array}{l}15 \\
09 \\
\text { ai }\end{array}$ & வே & 욤 & :0 \\
\hline 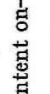 & $\overrightarrow{\dot{0}}$ & 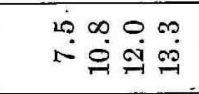 & $\stackrel{\substack{\mathfrak{N} \\
0}}{0}$ & تص & 告 & मे \\
\hline  & 离. & 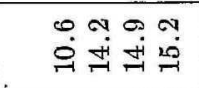 & $\underset{\sim}{\mathscr{S}}$ & 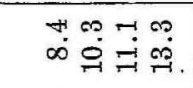 & ஓా &  \\
\hline$\approx$ & $\begin{array}{l}-1 \\
\dot{J} \\
\stackrel{0}{0}\end{array}$ & 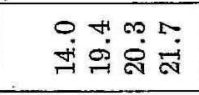 & $\underset{+i}{+}$ &  & $\begin{array}{l}\stackrel{9}{1} \\
\text { i }\end{array}$ & 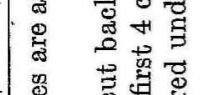 \\
\hline & $\frac{{ }_{0}^{2}}{2}$ & 点 & 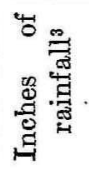 &  &  & 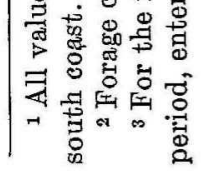 \\
\hline
\end{tabular}


a protein content of only 6.7 percent. That fertilized with 100 pounds of nitrogen had 8.8 percent protein while that fertilized with 400 pounds of nitrogen had 10.9 percent protein.

During the first year the application of 100 pounds of nitrogen per acre about doubled the quantity of protein carried over in the field, from 238 to 486 pounds per acre. Heavier applications of nitrogen did not significantly increase protein yields. Similar results were obtained during the second year.

\section{Residual effects}

The yields of dry matter during subsequent rainy seasons were not significantly affected by nitrogen fertilization. Total yields of dry matter produced during the first year, however, were significantly increased, from 9,710 pounds to 12,645 pounds per acre, by the application of 100 pounds of nitrogen per acre.

In general, nitrogen fertilization tended to increase protein yields and protein content of the forage produced during the residual yield periods. In some instances the effect of nitrogen fertilization was evident up to one year after application of the fertilizer. This residual effect of nitrogen fertilization was more marked during the second year when plant growth during the yield period immediately following application of the fertilizer was greatly curtailed by drouth.

During the first year the 400-pound level of nitrogen fertilizer signifcantly increased protein yields and protein content of the forage over the first residual yield period. This treatment as well as the 100-pound level of nitrogen significantly increased protein yields during the second residualyield period.

The total protein yields during this year were significantly increased by the application of 100 pounds of nitrogen fertilizer, from 608 to 921 pounds per acre. The 400-pound level of nitrogen caused a further significant increase in protein yields to 1,157 pounds per acre, and also significantly increased the protein content of the forage produced during this year.

During the second year the 100-pound level of nitrogen fertilizer significantly increased protein yields and protein content of the forage produced during both residual-yield periods. A further significant increase was brought about in both instances by the 400-pound level of nitrogen.

The 100-pound level of nitrogen caused a significant increase in total protein yields, from 511 pounds per acre to 740 pounds, and in protein content, from 5.4 to 7.0 percent, of the forage produced during this second year. The 400-pound level of nitrogen caused a further significant increase in total protein yields to 1,055 pounds per acre, and protein content to 10 percent. 


\section{Recovery of applied nitrogen}

Recovery in the forage of the applied nitrogen was rather low during both years. Highest recovery was at the 100-pound level of nitrogen with an average of about 50 percent during the first year and about 37 percent during the second. Over both years an average of only about 29 percent of the 200-pound application and only about 22 percent of the 400 -pound application was recovered. It is possible that, had yields been taken over a longer period following application of the fertilizer, a higher proportion of the nitrogen would have appeared in the forage as protein.

\section{Soluble-nitrogen content of forage}

In no case did the forage samples analyzed contain more than 0.5 percent of soluble nitrogen and values were usually considerably below this level. Only traces of nitrites were found. There thus seems to be little danger of the forage ever having been dangerously high in nitrogen compounds which could be toxic to livestock, and almost all the protein was apparently in a form which could be utilized by ruminants for their nutrition.

\section{DISCUSSION OF RESULTS}

The data obtained during the first year when rainfall conditions were normal show that, from a practical standpoint, the application of 100 pounds of nitrogen per acre was the most desirable. The amount of forage produced for carry-over into the critical dry season was increased 55 percent, from 3,555 to 5,520 pounds of dry matter per acre, by this treatment. Similarly, the protein content of the forage was increased 31 percent, from 6.7 to 8.8 percent, and protein yields 105 percent, from 238 to 486 pounds per acre. Residual yields of dry matter and protein tended to be increased by this treatment. Total dry-matter yields for the 1-year period were increased 30 percent, from 9,710 to 12,645 pounds per acre, and protein yields were increased 51 percent, from 608 to 921 pounds per acre. Furthermore, a much higher proportion of the nitrogen applied was recovered at this level of fertilization than with heavier applications of nitrogen.

Since forage is generally abundant during the wet season the stocking rate of farms is usually limited by the carrying capacity of the pastures during the dry season. Assuming 50-percent utilization of the forage by livestock and the consumption of 20 pounds of dry matter daily per head by mature animals, the carry-over forage produced by the unfertilized plots would provide only 88 animal-days of grazing during the 5 -month dry season, as contrasted with 138 animal-days which would be provided by the plots receiving 100 pounds of nitrogen fertilizer. Furthermore, the higher protein content of the fertilized forage would in all probability improve animal performance. Thus, with proper fertilization and pasture 
management, it is theoretically possible under the conditions of this experiment to maintain 1 head of livestock on every 11/4 acres throughout the critical dry season on carry-over forage. Such a level of stocking may be feasible where some silage or cane tops can be provided during the dry season but in general, 2 acres per head would seem to be a more practical goal. This compares favorably with the 3 to 4 acres required with Guinea grass pastures under present conditions.

The importance of careful management of these pastures cannot be overemphasized. Productivity of Guinea grass pastures in this area can be markedly increased by proper management alone. The pastures should not be overgrazed, especially toward the end of the wet season, and should be fenced to provide for rotational grazing, particularly during the dry season. Otherwise the animals will feed on the highly nutritious leaves during the beginning of the dry season and have only the less nutritious leaf sheaths and stems to graze on later. In order to obtain sufficient forage having a proper protein content for carry-over into the dry season, nitrogen fertilizer should be applied to closely grazed pastures during October or early November. These pastures should not be grazed again until forage becomes scarce during the dry season.

The results of this study indicate that livestock production in the nonirrigable, semiarid region of the Island can be appreciably increased by proper management and fertilization of Guinea grass pastures with nitrogen. Further increases may be obtained through the use of silage, which should be greatly expanded, but the potential for livestock production in this region appears to be generally limited by rainfall and topography.

\section{SUMMARY}

The stocking level and hence the productive capacity of pastures in the nonirrigable, semiarid region of Puerto Rico is limited by the pasturage available during the approximately 5-month dry season of December to April. This, in turn, largely depends on the quantity and quality of the roughage carried over in the field from the wet season when an excess of forage is produced.

The application of 100 pounds of nitrogen per acre to a closely grazed Guinea grass pasture toward the end of the wet season, November 1, resulted in a marked increase in the dry matter from 3,555 to 5,520 pounds per acre of protein yields from 238 to 486 pounds per acre, and in the protein content from 6.7 to 8.8 percent, of the forage carried over in the field for grazing toward the end of the dry season.

Total yields of dry forage produced during the year following application of the fertilizer were increased from 9,710 to 12,645 pounds per acre. Total yields of protein were also increased by this treatment from 608 to 921 
pounds per acre. About 50 percent of the nitrogen applied was recovered in the forage. Heavier applications of nitrogen tended to increase protein yields and also the protein content of the forage, but did not affect yields of dry matter.

Through good management and proper fertilization with nitrogen it appears possible markedly to increase the carrying capacity of Guinea grass pastures in this area.

\section{RESUMEN}

La producción de los pastos de yerba Guinea en la costa semi-árida de Puerto Rico depende en gran parte de la calidad y cantidad de forraje que pueda conservarse en el campo durante la época de lluvia, cuando abunda el pasto, para ser pastoreado luego durante la sequía.

Mediante la aplicación de 100 libras de nitrógeno por cuerda antes de comenzar la sequía se aumentó la cantidad de forraje seco conservado en el campo de 3,555 a 5,520 libras por cuerda, la cantidad de proteína de 238 a 486 libras por cuerda y el contenido de proteína del forraje de 6.7 a 8.8 por ciento. El rendimiento de forraje seco producido durante el año subsiguiente a la aplicación de nitrógeno también aumentó de 9,710 libras a 12,645 libras por cuerda. Asimismo la producción de proteína aumentó de 608 a 921 libras por cuerda. Se recobró en el forraje más o menos la mitad del nitrógeno aplicado. Aplicaciones mayores de nitrógeno aumentaron el contenido de proteína pero no el rendimiento de la yerba.

Mediante el manejo y abonamiento adecuado es posible aumentar considerablemente la producción de los pastos de yerba de Guinea en la región semi-árida de Puerto Rico. 